\title{
ОСОБЛИВОСТІ ПІДГОТОВКИ ПЕДАГОГІЧНИХ КАДРІВ В УНІВЕРСИТЕТІ
}

\begin{abstract}
У статті розглянуто проблему спещифіки підготовки педагогічних кадрів на заняттях у вищій школі як одного з чинників їхньої професійно-творчої самореалізаиії.

Ключові слова: університет, кваліфіковані педагогічні кадри,особистість педагога, професійна усталеність вчителя.
\end{abstract}

В статье рассматривается проблема специфики подготовки педагогических кадров на занятиях в высшей школе как одного из факторов их профессионально-творческой самореализачии.

Ключевые слова: университет, квалифицированные педагогические кадры, личность учителя, профессиональная устойчивость учителя.

The article deals with the problem of teachers' training specificity at high school as a factor in their professional and creative self-realization.

Key words: university, qualified teaching staff, the identity of a teacher, teacher's professional resistance.

Система освіти й виховання - головне джерело посилення інтелектуального й культурного потенціалу суспільства. Ключова позиція в цій системі належить викладачеві, який визначає прогрес загальноосвітньої, середньої спеціальної й вищої школи, тому його професійне формування, становлення й діяльність становлять пріоритетний напрямок у теорії й практиці освіти й виховання.

Теоретичною основною є теоретична база й науковий апарат, розроблені в дослідженнях учених зі специфіки підготовки педагогічних кадрів з університетською освітою (Є. Білозерцев, В. Кан-Калик, В. Краєвський, Н. Кульміна, 3. Курлянд, Н. Мєшков, Л. Нечепоренко, Г. Нікандров, Г. Саранцев, А. Троцько); за структурою і змістом вищої освіти (К. Ушинський, М. Пирогов); із проблем формування основ педагогічного професіоналізму у студентів університету (Т. Руднєва, В. Антипова, А. Арет); відповідно до можливостей відродження класичної університетської освіти (А. Сухарев, С. Бреев, В. Болотов); з питань розвитку особистісних якостей і педагогічної спрямованості студентів як майбутніх педагогів (І. Зязюн, В. Сластьонін, М. Воробйов, Б. Лихачов, Н. Тализіна, В. Буряк, Л. Кондрашова). Значний внесок у розроблення цього дослідження зробили роботи цих учених, що стосуються формування у студентів педагогічних умінь і навичок в умовах університетської освіти.

Meта cmammi - зробити системний аналіз проблеми підготовки педагогічних кадрів 3 університетською освітою.

Успіх освітнього процесу за всіх часів багато в чому залежав від освіченості, рівня ерудиції й загальної культури, професійної майстерності педагога. Відповідальність учителя в навчальновиховному процесі націй завжди була досить високою. Одним із головних завдань педагога $\epsilon$ здійснення зв'язку часів, тому що кожний учитель і викладач, образно говорячи, передає естафету із сьогодення в майбутнє. Відповідно до цього, гостро постає проблема професійної підготовки педагогічних кадрів в умовах українського суспільства, виявлення позитивних і негативних рис формування особистості педагога.

Традиційно підготовка кваліфікованих педагогічних кадрів пов'язана 3 діяльністю вищих навчальних закладів, а саме університетів.

Ця проблема не $\epsilon$ новою. У різні періоди розвитку нашого суспільства успішна діяльність університетів розглядалася як один із найважливіших показників благополуччя держави. Заклопотаність низьким рівнем професійної підготовки, пошуки шляхів іiі подальшого вдосконалювання породили багато думок, які викладалися у статтях, виступах на педагогічних з’їздах і нарадах шкільних наставників і професорів вищих навчальних закладів. Н. Терехова підкреслює, що вивчення основних відмітних рис університетської педагогічної підготовки висуває головні вимоги до студентів як до майбутніх учителів: «розвиток творчого мислення, навичок дослідницької роботи, самостійного, нешаблонного підходу до розв'язання практичних завдань, потреба в постійному поповненні знань, подальшій самоосвіті» [5, с. 21].

Відповідність сучасного вчителя-фахівця зазначеним найважливішим вимогам $\epsilon$ відмітною рисою університетської підготовки педагогічних кадрів. Університети як навчальні заклади, які готують викладачів, завжди відігравали виняткову роль у системі народної освіти, й особлива увага приділялася саме якості професійної підготовки університетського студентства, яке за всіх часів становило «золотий фонд» викладацьких кадрів для школи.

Університет (від лат. universitas - сукупність) - це багатопрофільний вищий навчальний заклад, де готують висококваліфіковані кадри 3 широкого кола спеціальностей у галузі природних, суспільних та гуманітарних наук [1, с. 339].

У зв'язку із зазначеним головна складність університетської підготовки педагогічних кадрів полягає в тому, що університет - це педагогічна система, що має багатоцільове призначення, i навчання вчителів здійснюється в умовах подвійної (наукова або педагогічна діяльність), а на деяких 
факультетах і потрійний (наукова, виробнича й педагогічна діяльність) орієнтації. Як зазначає Н. Терехова, звідси й зафіксоване в дослідженнях зниження первісного рівня педагогічної спрямованості студентів університету, а також слабка професійна стійкість його випускників [5]. Навчання в університеті, де студент має можливість вступити в безпосередній контакт із ученимвикладачем і розділяє його інтерес і систематизований аналіз предмета, припускає формування, в основному, наукової спрямованості в студентів, приділяючи недостатньо уваги педагогічним навичкам.

Загальнонаукова, фундаментальна підготовка в більшості університетів здійснюється, на жаль, на занепад психолого-педагогічній, проте, вважається головною перевагою університетів. Не викликає сумніву той факт, що загальнонаукова підготовка становить основу підготовки в університеті фахівця будь-якої кваліфікації. Водночас випускникам деяких факультетів привласнюється подвійна кваліфікація, яка передбачає їхню подальшу діяльність у якості як фахівців обраної галузі науки, так і iii викладачів. Не можна забувати, що основними споживачами професійних кадрів із числа випускників усіх педагогічних спеціальностей університету є загальноосвітні школи, а тому високий рівень науково-теоретичної підготовки не може компенсувати недоліка психолого-педагогічних знань і вмінь. Очевидно, що в особистості вчителя стають цінними не тільки глибокі знання як такі, але й уміння їх передати наступним поколінням, досягаючи тим самим потрібного виховного результату.

Університет як особлива педагогічна система забезпечує глибоку теоретичну підготовку випускників до майбутньої науково-практичної й педагогічної діяльності.

Щоб забезпечити динамізм, рухливість у підготовці педагогічних кадрів, необхідно уточнити цілі педагогічної освіти, іiі зміст, методику й технологію відповідно 3 тенденціями, які визначають розвиток загальної освіти, і принципами ії випередження.

У структурі цілей і завдань підготовки фахівців-педагогів у ВНЗ можна виокремити інваріантну складову, пов'язану із цілями й завданнями забезпечення педагогічного процесу як такого, i варіативну - коригувальну, що відбиває вплив на здійснюваний процес конкретно-історичних факторів (політичних, ідеологічних, економічних). Інваріантна складова становить своєрідне «ядро» педагогічного процесу, яке виражає його вищий, незмінний зміст, пов'язаний із забезпеченням відтворення суспільства, шляхом передачі навичок і розкриття творчого потенціалу учнів. Цей фактор характеризується стабільністю, наступністю між поколіннями основних педагогічних принципів, орієнтацією педагогічного процесу на вищі гуманістичні цінності.

Друга група чинників спрямована на гармонізацію форм підготовки педагогічних кадрів 3 реальними умовами відтворення суспільства; вони виконують адаптивну функцію, набудовуючи зазначену систему на розв'язання принципових завдань, які стоять перед суспільством у той або інший момент його розвитку з обліком його реальних можливостей і глобальних цілей.

Сучасний учитель загальноосвітньої школи, на жаль, нині має труднощі в орієнтуванні поміж сучасних тенденцій розвитку сучасної педагогічної думки - підвищувати ефективність своєї праці, слідкувати за новітніми досягненнями й педагогічним досвідом. Його знання і кваліфікація швидше $є$ відповідними до колишніх умов викладання, а не майбутніх. Як наслідок, випускники педагогічних навчальних закладів часто роблять різні педагогічні помилки, часом несвідомо.

Слід ретельніше й глибше вивчати проблеми підготовки кадрів і здійснення заходів щодо “ї розв'язання. Задля цього треба використовувати в повному обсязі сучасні знання про специфіку й особливості педагогічної структури, що, зрештою, має забезпечити успіх професійної адаптації молодого вчителя. Сьогодення вимагає, щоб до сучасної школи йшли вчителі свідомі, які мають сформовану світоглядну, професійну й моральну позицію.

Тому в зазначеному вище контексті відповідну підготовку кадрів бажано було б спрямовувати на розв'язання певних завдань: а) оновлення змісту та навчально-методичного забезпечення підготовки й підвищення кваліфікації педагогічних кадрів, що забезпечить їхню методологічну підготовку; б) розроблення нових технологій підготовки й підвищення кваліфікації педагогічних кадрів, що відображає рівень розвитку сучасних фундаментальних і прикладних наук, диференціацію й індивідуалізацію навчання.

Вимоги до вчителя школи передбачають наявність у нього таких рис, як наполегливість в удосконаленні педагогічного професіоналізму.

У сучасних умовах учитель має бути не стільки передавачем знань і ставлень, скільки вмілим координатором чи керівником процесу оволодіння кожним зі своїх учнів усією палітрою й багатством суспільного спадку. Вчитель має управляти цим процесом заради власного саморозвитку та розвитку здібностей кожного з учнів. Це означає постійний пошук учителем нових способів залучення до навчально-виховного процесу індивідуальних здатностей кожного учня та соціальних умов його буття, вміння поєднати потреби й здібності особистості учня з його пізнавальною й трудовою діяльністю.

Якщо нині загальноосвітня школа орієнтується не на тран-сляцію знань, а на розвиток індивідуальності, формування творчої особистості учнів, то випускники педагогічних ВНЗ і 
університетів повинні на відповідному рівні володіти технологіями виховуючого й розвивального навчання.

Готовність до ризику, імпульсивність і поривчастість, стійка схильність до активної діяльності, енергія, наполегливість і завзятість, підвищена працездатність і виняткова зосередженість на предметі діяльності характеризують вольовий аспект творчої активності сучасного вчителя.

Критичний аналіз практики підготовки педагогічних кадрів і рівня їхньої професійної готовності свідчить про необхідність кардинальних змін. За даними анкетування 28,7\% опитаних молодих учителів загальноосвітніх і спеціалізованих шкіл м. Кривого Рогу зі стажем роботи менш 3-х років упевнені в успішності своєї професійної діяльності. Тільки 6,9\% без коливань і труднощів долучалися до самостійної педагогічної роботи. Більша частина 3 опитаних молодих учителів були критично налаштовані щодо їхньої підготовки до професійної діяльності. 55\% - указують на розбіжність між теоретичними знаннями, отриманими в університеті, і тими практичними, які необхідні в школі. 78\% молодих учителів указали на свою непідготовленість до педагогічної діяльності, виховної роботи 3 дітьми; 59,9\% - до навчальної роботи, з урахуванням тих вимог, які суспільство висуває до сучасної школи. Вивчення й аналіз роботи молодих починаючих учителів дозволяють говорити не тільки про недолік професійно-педагогічних знань і вмінь, але й про низький рівень активності професійної позиції і творчого стилю їхньої діяльності.

Молоді вчителі, після закінчення педагогічного університету, головне своє призначення бачать у передачі знань, тобто у викладі навчального матеріалу, не замислюючись при цьому про виховний i розвивальний ефект навчання. Таку ситуацію можна пояснити тим, що вища педагогічна школа залишається орієнтованою на підготовку вчителів-предметників, передавачів знань.

Кожний учитель, професійно підготовлений до викладацької діяльності, має знати, що виховання і навчання у школі тісно взаємозв'язані й зорієнтовані на те, щоб формувати в учня бажання й уміння вчитися, задовольняти безпосередні інтереси до пізнання навколишнього світу й самого себе, разом із сім'єю навчити гуманної й етичної поведінки.

Зростаючі вимоги до особистості сучасного вчителя, до рівня його професіоналізму й характеру педагогічної діяльності визначають необхідність модернізації професійної підготовки педагогічних кадрів в умовах вищої школи. Аналіз практики ВНЗ дозволяє говорити про те, що традиційна система навчання студентів не повною мірою відповідає новим вимогам, що висуваються до рівня їхнього професіоналізму. Орієнтація на предметне навчання, ігнорування індивідуальності, перевага репродукції в навчальному процесі негативно позначається і на рівні творчої активності майбутніх учителів.

Завдання полягають у тому, щоб змінити позицію студента в навчальному процесі 3 пасивного $і$ стороннього спостерігача (у якій він перебуває під час традиційної організації занять у вищій школі) на активного учасника навчальної роботи, суб'єкта власного утворення і професійного саморозвитку, самоствердження.

Оскільки творча активність майбутнього вчителя - це його здатність до цілеспрямованої i планомірної педагогічної діяльності щодо формування духовних цінностей у себе й учнів, важливо змінити характер професійно-педагогічної підготовки таким чином, щоб учити студентів умінню звільнятися від шаблону, стереотипу і заборон, умінню брати на себе ініціативу пошуку нового, невідомого й розвивати в них здатність до свідомого самоконтролю, організованості, творчого розв'язання навчальних завдань.

Це можливо лише в тому випадку, якщо переорієнтувати навчальний процес із предметного на особистісно орієнтоване навчання.

На сучасному етапі розвитку освітньої системи існує ни-зка значних недоліків в університетській педагогічній освіті. По-перше, в університетах недостатньо часу приділяється на вивчення дисциплін психолого-педагогічного курсу, а також у студентів не вистачає практичних умінь і навичок через малу кількість педагогічної практики протягом навчального процесу. По-друге, викладання більшості наукових дисциплін здійснюється не відповідно до їх застосування в подальшому викладанні навчальних предметів у загальноосвітній школі. По-третє, дотепер не повною мірою розроблено цілісний підхід до основних парадигм університетської педагогічної освіти: не визначено загальні цілі й завдання, централізовано не погоджено змісту педагогічної освіти в університеті, не вироблено загальних форм i методів навчання педагогіці. Тому проблема концепції університетської педагогічної освіти залишається досить актуальною й гострою в сучасній педагогічній теорії й практиці. У зв’язку із цим, покращення підготовки педагогічних кадрів в університеті повинне бути спрямоване на постійне зростання якості професійно-педагогічної підготовки майбутнього вчителя, формування необхідних для викладацької діяльності особистісних якостей, а також створення умов для розвитку необхідної складової успішної педагогічної роботи - педагогічної спрямованості і професійної готовності.

1. Гончаренко С. У. Український педагогічний словник / Семен Устимович Гончаренко. - К. : Либідь, 1997. - 375 с. 2. Курлянд 3. Н. Професійна усталеність вчителя - основа його педагогічної майстерності / 3. Н. Курлянд. - Одеса, 1995. - 160 с. 3. Сластёнин В. А. Формирование личности учителя советской школы в процессе профессиональной подготовки / Виталий Александрович Сластёнин. - М. : Просвещение, 1976. 
160 с. 4. Талызина Н. Ф. Педагогическая психология: [уч. пособ.] / Н. Ф. Талызина. - [5-е изд.] - М. : Академия, 1998. - 288 с. 5. Терехова Н. Г. Совершенствование системы профессионального отбора молодежи на педагогические специальности университетов / Н. Г. Терехова. - Бишкек : БГУ, 1992. - 176 с. 